\title{
Supporting-Electrolyte-Free and Scalable Flow Process for the Electrochemical Synthesis of 3,3',5,5'-Tetramethyl-2,2'-biphenol
}

\author{
Maximilian Selt ${ }^{\mathrm{a}}$, Robert Franke ${ }^{\mathrm{b}, \mathrm{c}}$, Siegfried R. Waldvogel ${ }^{\mathrm{a} *}$ \\ aDepartment of Chemistry, Johannes Gutenberg University Mainz, Duesbergweg 10-14, \\ 55128 Mainz, Germany \\ ${ }^{\mathrm{b}}$ Evonik Performance Materials GmbH, Paul-Baumann- Straße 1, 45772 Marl, Germany \\ 'Lehrstuhl für Theoretische Chemie, Ruhr-Universität Bochum, 44780 Bochum, Germany
}




\section{Table of Content}

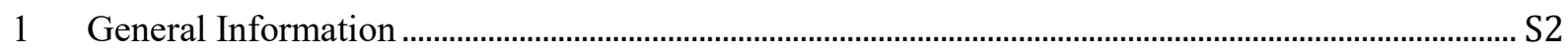

2 General Protocol for the Electrochemical Synthesis of 3,3',5,5'-Tetramethyl-2,2'-biphenol .......... S4

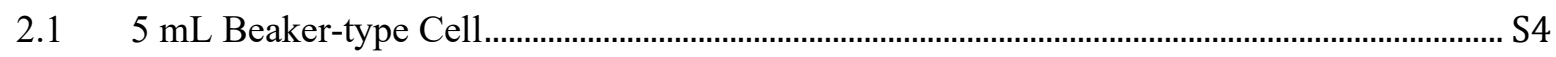

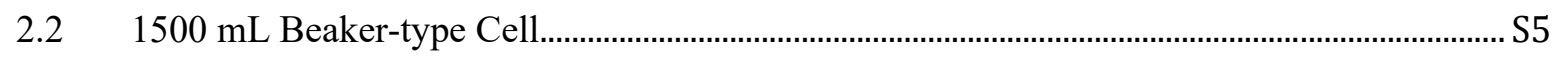

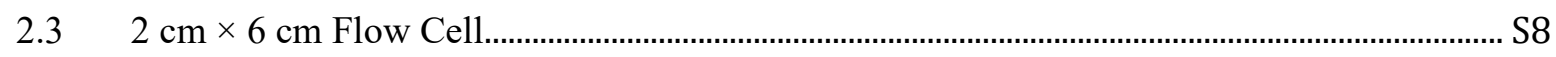

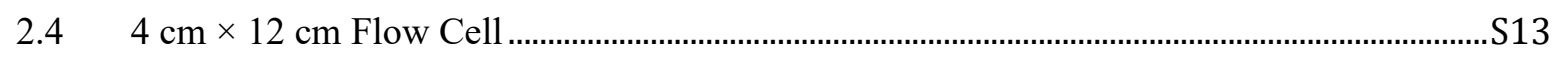

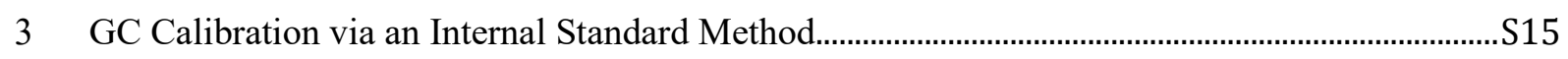

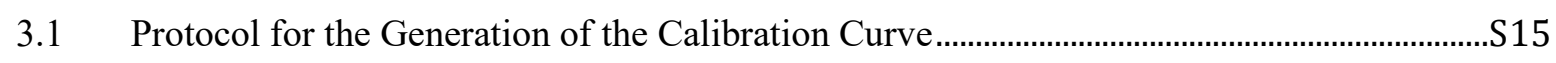

3.2 Protocol for the Analysis of an Electrolyte Sample..................................................................... 16

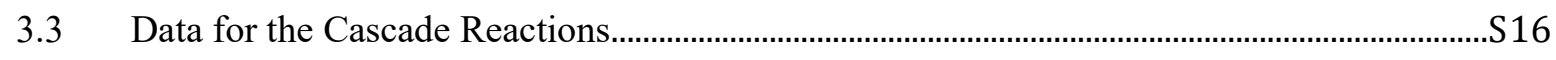

4 Analytical Data of 3,3',5,5'-Tetramethyl-2,2'-biphenol (2) .........................................................S2

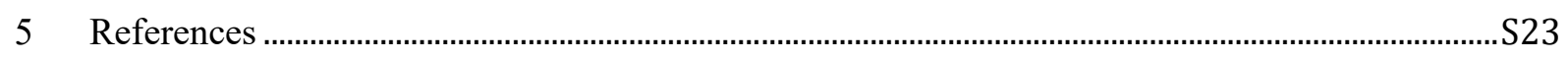




\section{General Information}

All of the reagents used were analytical grade. Solvents were purified by standard methods. ${ }^{1}$

As a power supply for the $5 \mathrm{~mL}$ beaker-type cells, a self-built eight-channel galvanostat with an integrated Coulomb counter of University Bonn (each channel dc output 0-50 V and 0-50 mA) was used. ${ }^{2} \mathrm{~A}$ similar setup for the $5 \mathrm{~mL}$ batch reactions is also commercially available as the IKA Screening System (IKA-Werke GmbH \& Co. KG, Staufen, Germany, https://www.ika.com/de/Produkte-LabEq/Screening-System-csp-913/, 2020-02-20). As a power supply for the $2 \mathrm{~cm} \times 6 \mathrm{~cm}$ flow cell, a selfbuilt one-channel galvanostat ( $\mathrm{dc}$ output $0-70 \mathrm{~V}$ and $0-1 \mathrm{~A}$ ) and a self-built Coulomb counter of University Bonn were used. The electrochemical $2 \mathrm{~cm} \times 6 \mathrm{~cm}$ flow cell is also commercially available as ElectraSyn flow (IKA Werke, http://www.ikaprocess.de/Produkte/Kontinuierliche-Elektroysenthesecph-45/, 2020-02-20). For the $4 \mathrm{~cm} \times 12 \mathrm{~cm}$ flow cell, a TDK Lambda Z60-3.5 power supply (TDK Lambda, Achern, Germany; dc output 0-60 V and 0-3.5 A, rated power $210 \mathrm{~W}$ ) was used. The electric current was adjusted for the given current density, whereas the voltage was set freely.

For pumping the electrolytes through the $2 \mathrm{~cm} \times 6 \mathrm{~cm}$ flow cell an Ismatec Reglo ICC MS-2/12 digital peristaltic pump (Cole-Parmer GmbH, Wertheim, Germany; two channels, 12 pump rollers, flow rate of $0.002-38 \mathrm{~mL} / \mathrm{min}$ per channel) with PharMed BPT tubing (IDES Health \& Science GmbH, Wertheim, Germany; $0.25 \mathrm{~mm}$ I.d., $0.90 \mathrm{~mm}$ wall and $2.06 \mathrm{~mm}$ i.d., $0.91 \mathrm{~mm}$ wall)) was used, and for pumping elektrolyste through the $4 \mathrm{~cm} \times 12 \mathrm{~cm}$ flow cell, a Fink Ritmo R033/7-16 pump (Fink Chem + Tec GmbH, Leinfelden-Echterdingen, Germany; flow rate of $0.0417-125 \mathrm{~mL} / \mathrm{min}$, maximal pressure of 16 bar, maximal stroke frequency of 190 strokes/min, stroke volume of $0.74 \mathrm{~mL}$ ) was used.

For external temperature control, a Julabo F33-MA refrigerated circulator (Julabo GmbH, Seelbach, Germany; working temperature, $-30^{\circ} \mathrm{C}$ to $200{ }^{\circ} \mathrm{C}$; heating power, $2 \mathrm{~kW}$; cooling power (ethanol), 0.5 $\mathrm{kW}\left(20^{\circ} \mathrm{C}\right), 0.32 \mathrm{~kW}\left(0{ }^{\circ} \mathrm{C}\right), 0.12 \mathrm{~kW}\left(-20^{\circ} \mathrm{C}\right), 0.03 \mathrm{~kW}\left(-30^{\circ} \mathrm{C}\right)$; flow rate, $\left.11-16 \mathrm{~L} / \mathrm{min}\right)$.

Column chromatography was performed on a Sepacore Flash Systems X10 / X50 preparative chromatography system (Büchi Labortechnik AG, Flawil, Switzerland) with a Büchi C-620 control unit, a Büchi UV Photometer C-635 UV detector, a Büchi C-660 fraction collector and two C-605 pump modules to adjust the solvent mixture. A $90 \mathrm{~g}$ disposable polypropylene cartridge filled with silica gel 
$60 \mathrm{M}(0.060-0.200 \mathrm{~mm}$, Macherey-Nagel GmbH \& Co., Düren, Germany) was used for column chromatographic separation. Mixtures of cyclohexane purified in the rotary evaporator (solvent A) and ethyl acetate (solvent B) were used as eluents. The following gradient was run at a flow rate of $75 \mathrm{~mL} / \mathrm{min}$ and a maximum pressure of 10 bar: $12 \min 0 \mathrm{~s}, 0 \%$ solvent $\mathrm{B} ; 20 \min 5 \mathrm{~s}, 0-1 \%$ solvent B; $15 \min 0 \mathrm{~s}, 1-2 \%$ solvent $\mathrm{B} ; 12 \min 5 \mathrm{~s}, 2-4 \%$ solvent $\mathrm{B} ; 5 \min 5 \mathrm{~s}, 4-8 \%$ solvent $\mathrm{B} ; 5 \min 5 \mathrm{~s}, 8-16 \%$ solvent B; 5 min 5 s, $16-32 \%$ solvent B; $5 \min 5$ s, $32-100 \%$ solvent B; 5 min 0 s, $100 \%$ solvent B.

Melting points were determined with a Melting Point Apparatus B-545 (Büchi, Flawil, Switzerland) and were uncorrected. Heating rate: $2^{\circ} \mathrm{C} / \mathrm{min}$.

Gas chromatography was performed on a Shimadzu GC-2010 chromatograph (Shimadzu, Japan) using a ZB-5 column (Phenomenex, USA; length, $30 \mathrm{~m}$; inner diameter, $0.25 \mathrm{~mm}$; film, $0.25 \mathrm{~mm}$; carrier gas, hydrogen). GC-MS measurements were carried out on a Shimadzu GC-2010 chromatograph (Shimadzu, Japan) using a ZB-5 column (Phenomenex, USA; length, $30 \mathrm{~m}$; inner diameter, $0.25 \mathrm{~mm}$; film, 0.25 mm; carrier gas, hydrogen). The method was coupled with mass spectrometry on a Shimadzu GCMSQP2010.

Spectroscopy and spectrometry: ${ }^{1} \mathrm{H}$ NMR spectra were recorded at $25{ }^{\circ} \mathrm{C}$ by on a Bruker Avance III HD 400 NMR spectrometer (400 MHz) or (5 mm BBFO-SmartProbe with z gradient and ATM, SampleXPress 60 sample changer, Analytische Messtechnik, Karlsruhe, Germany). Chemical shifts ( $\delta$ ) are reported in parts per million (ppm) relative to TMS as an internal standard or traces of $\mathrm{CHCl}_{3}$ in the corresponding deuterated solvent. Mass spectra are obtained by using a MAT 95 (Finnigan, Germany) apparatus employing FD. 


\section{General Protocol for the Electrochemical Synthesis of 3,3',5,5'- Tetramethyl-2,2'-biphenol}

\subsection{5 mL Beaker-type Cell}

$307 \mathrm{mg}$ (2.5 mmol) 2,4-Dimethylphenol (1) and $0.25 \mathrm{~mL}$ of the amine (DMAP: $396 \mathrm{mg}, 3.24 \mathrm{mmol}$ )

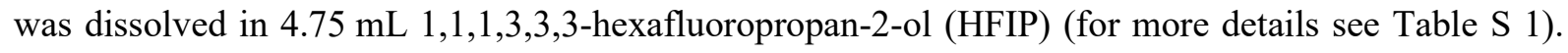
The solution was transferred into a $5 \mathrm{~mL}$ beaker-type cell equipped with BDD electrodes. A constant current electrolysis with a current density of $7.2 \mathrm{~mA} / \mathrm{cm}^{2}\left(1.8 \mathrm{~cm}^{2}\right.$ immersed anode surface, $\left.13 \mathrm{~mA}\right)$ was performed at $50^{\circ} \mathrm{C}$. After application of $242 \mathrm{C}(1.0 \mathrm{~F}$ per mole of $\mathbf{1})$ the electrolysis was stopped and the solvent was recovered in vacuo $\left(50^{\circ} \mathrm{C}, 200-70 \mathrm{mbar}\right)$. The crude coupling product was purified by column chromatography ( $\mathrm{SiO}_{2}$, cyclohexane/ethyl acetate) and dried under reduced pressure to obtain the pure product.

Table S 1. Screening of different amine-based additives for the electrochemical synthesis of 3,3',5,5'-tetramethyl-2,2'biphenol (2).

\begin{tabular}{|c|c|c|c|c|c|}
\hline Entry & Amine & $\begin{array}{c}\text { Volume fraction } \\
(\mathrm{vol} \%)\end{array}$ & $\begin{array}{c}\text { Mass } \\
(\mathrm{mg})\end{array}$ & $\begin{array}{c}\text { Amount of Substance } \\
(\mathrm{mmol})\end{array}$ & $\begin{array}{c}\text { Yield of 2 } \\
(\%)^{\mathrm{a}}\end{array}$ \\
\hline 1 & DIPEA $^{\mathrm{b}}$ & 5 & 190 & 1.47 & 57 \\
\hline 2 & pyridine & 5 & 245 & 3.10 & 69 \\
\hline 3 & 2-picoline & 5 & 243 & 2.61 & 54 \\
\hline 4 & $2,6-$-lutidine & 5 & 237 & 2.21 & 47 \\
\hline 5 & $\begin{array}{c}2,4,6- \\
\text { collidine }\end{array}$ & 5 & 226 & 1.86 & 51 \\
\hline 6 & DMAP & - & 396 & 3.24 & 46 \\
\hline
\end{tabular}

alsolated yield. bDIPEA $=N, N$-Diisopropylethylamine. cDMAP $=4$-Dimethylaminopyridine.

A detailed description of this set up was published recently (Figure S 1). ${ }^{2}$ This setup is also commercially available as IKA Screening System (IKA-Werke GmbH \& Co. KG, Staufen, Germany). Dimensions of BDD electrodes (15 $\mu \mathrm{m}$ diamond layer on silicon, DIACHEM ${ }^{\mathrm{TM}}$ obtained from CONDIAS, Itzehoe, Germany) are $7.0 \times 1.0 \times 0.3 \mathrm{~cm}$. Using a $5 \mathrm{~mL}$ reaction mixture, electrodes immersed $1.8 \mathrm{~cm}$ into the electrolyte. 


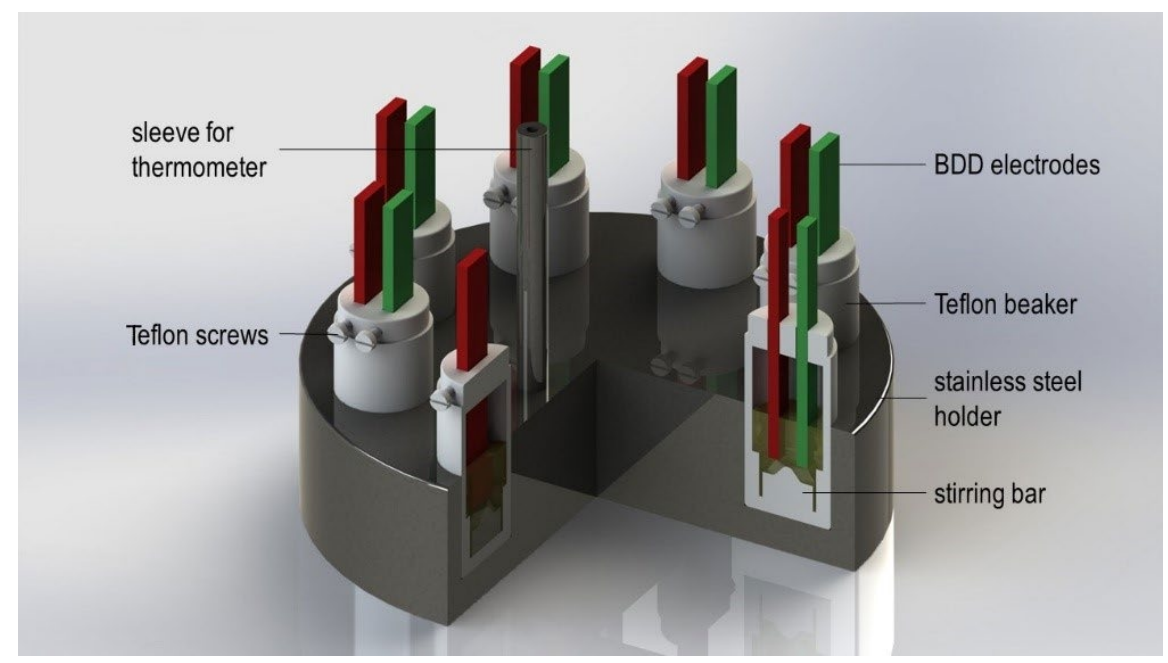

Figure S 1. Schematic view of undivided screening cells in a screening arrangement. ${ }^{2}$

\section{$2.21500 \mathrm{~mL}$ Beaker-type Cell}

$122.3 \mathrm{~g}$ (1.0 mol) 2,4-Dimethylphenol (1) and $50 \mathrm{~mL}$ pyridine was dissolved in $830 \mathrm{~mL}$ HFIP giving a total volume of $1000 \mathrm{~mL}$. The solution was transferred into a beaker-type cell equipped with six glassy carbon electrodes. The electrodes were connected alternating as anode and cathode, leading to five interelectrode gaps with an immersed anode surface of $195 \mathrm{~cm}^{2}$. A constant current electrolysis with a current density of $5 \mathrm{~mA} \cdot \mathrm{cm}^{-2}$ was performed at $50{ }^{\circ} \mathrm{C}$. After application of $96596 \mathrm{C}(1.0 F$ per mole of $\mathbf{1})$ the electrolysis was stopped and the solvent was almost completely recovered in vacuo $\left(50{ }^{\circ} \mathrm{C}, 200\right.$ 70 mbar), just until crystallization of the product occured. To complete the crystallization, the mixture was placed in the refrigerator $\left(8^{\circ} \mathrm{C}\right)$ overnight. The product was filtered off with suction and washed with cyclohexane. The solvent of the mother liquor was removed in vacuo $\left(50^{\circ} \mathrm{C}, 200-20 \mathrm{mbar}\right)$ and the residue was boiled three times in $250 \mathrm{~mL} n$-heptane to extract remaining product from the mother liquor. The extracts were united and $n$-heptane was evaporated in vacuo $\left(50{ }^{\circ} \mathrm{C}, 200-70\right.$ mbar $)$, just until crystallization of the product occured. To complete the crystallization, the mixture was placed in the freezer $\left(-30^{\circ} \mathrm{C}\right)$ overnight. The product was filtered off with suction, washed with cyclohexane and dried under reduced pressure. The combined product fractions gave $76.0 \mathrm{~g}$ ( $63 \%$ yield) of 2 .

A detailed depiction of this set up can be seen in Figure S 2, Figure S 3 and, Figure S 4. Dimensions of glassy carbon electrodes (SIGRADUR ${ }^{\circledR}$ G, obtained from HTW Hochtemperatur Werkstoffe GmbH, 
Thierhaupten, Germany) are $22.0 \times 7.0 \times 0.3 \mathrm{~cm}$. Using a $1000 \mathrm{~mL}$ reaction mixture, all six electrodes result in a total immersed anode surface of $195 \mathrm{~cm}^{2}$.

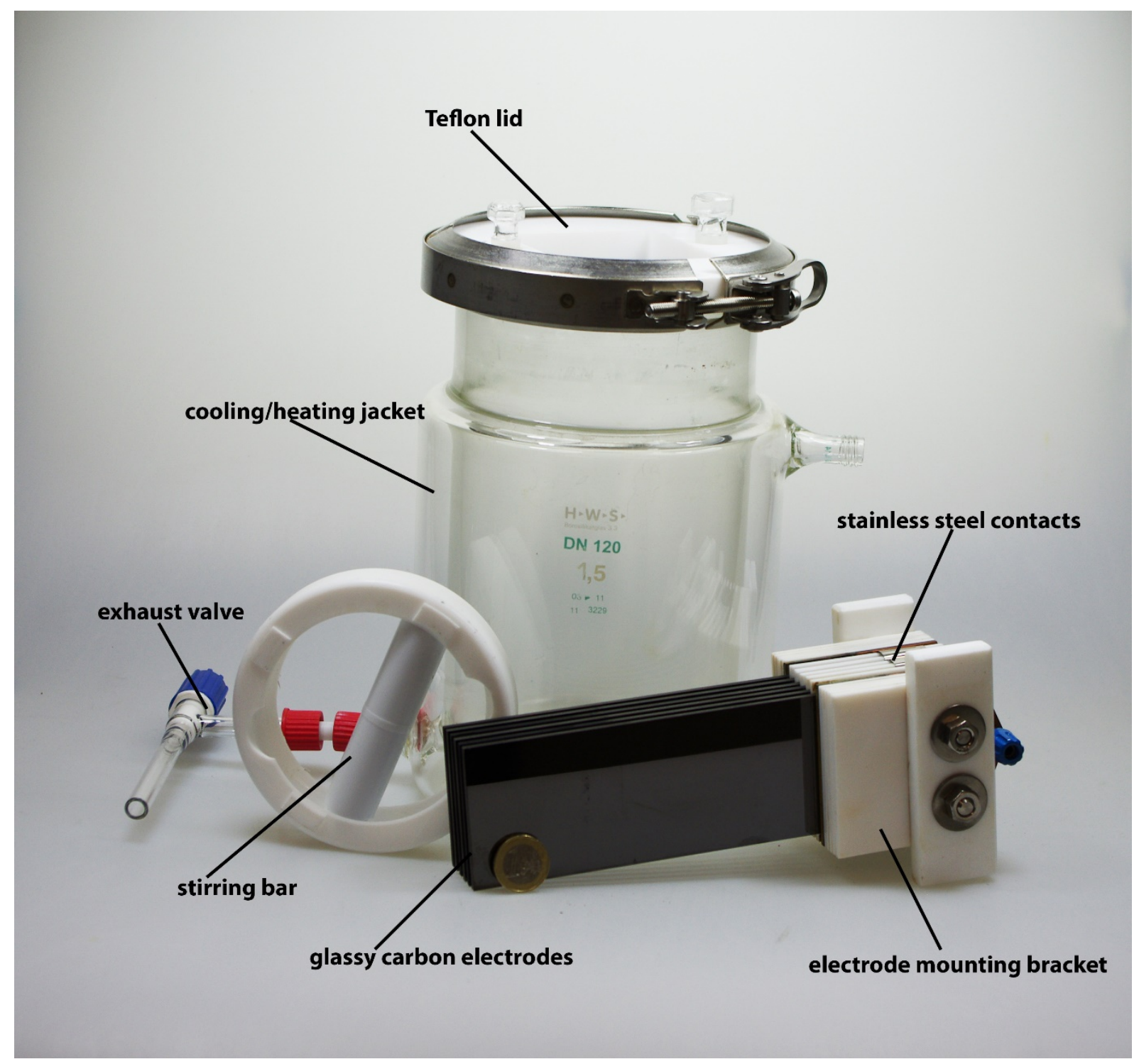

Figure S 2. Picture of the $1500 \mathrm{~mL}$ undivided beaker-type electrolysis cell and a one Euro coin (diameter: $23.25 \mathrm{~mm}$ ) for comparison. Essential parts are labelled. 


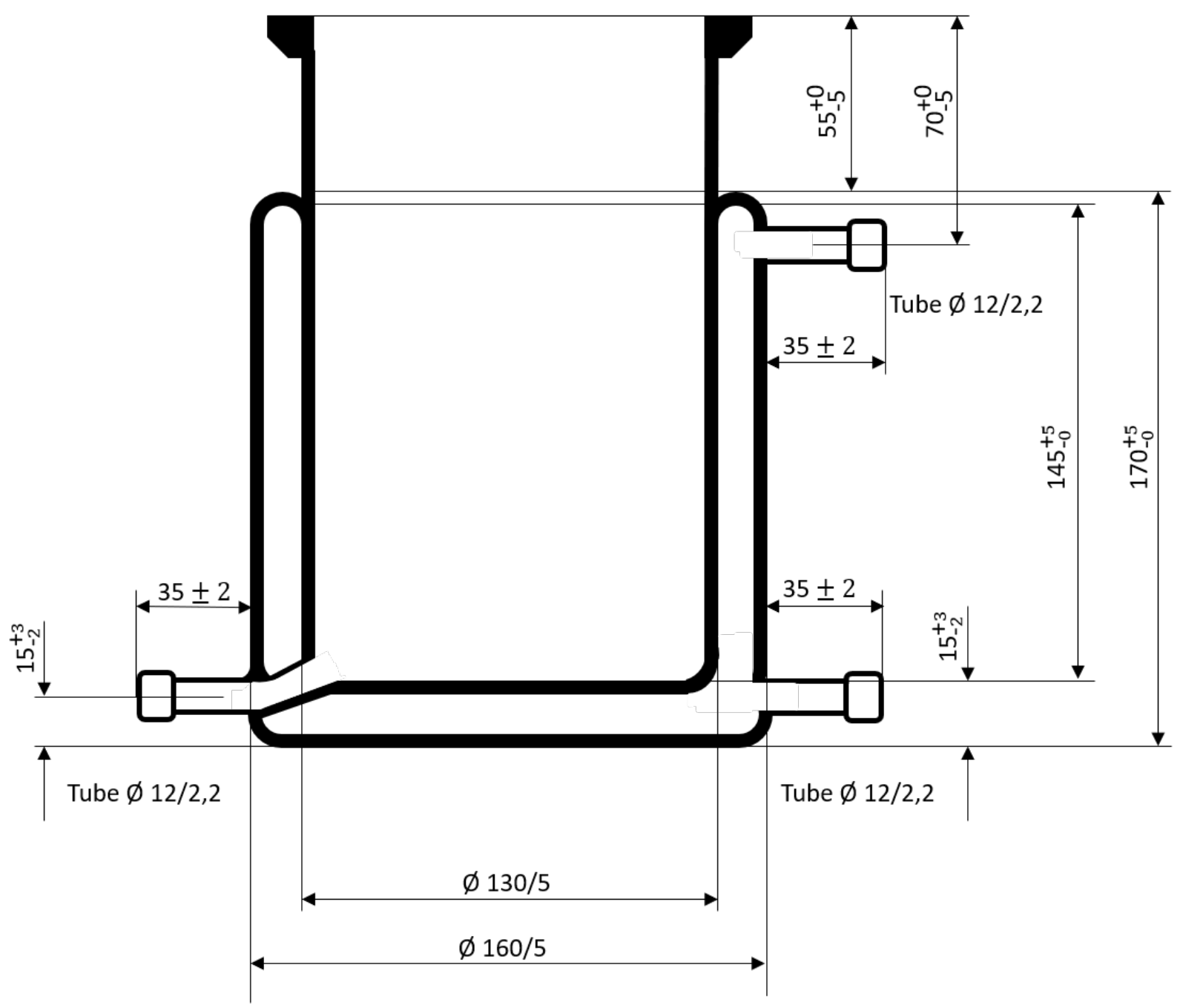

Figure S 3. Technical drawing of the $1500 \mathrm{~mL}$ undivided beaker-type electrolysis cell. 

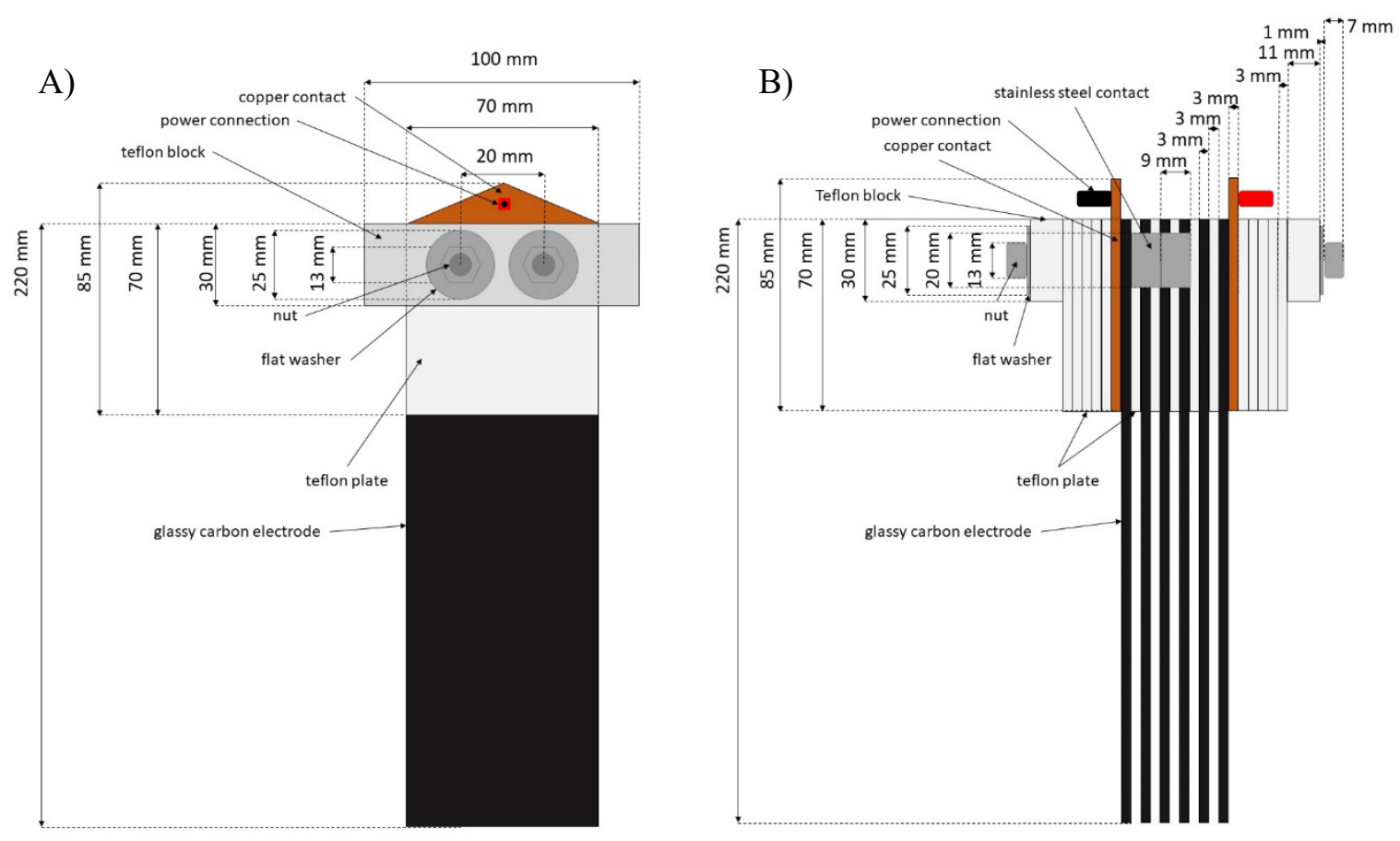

C)
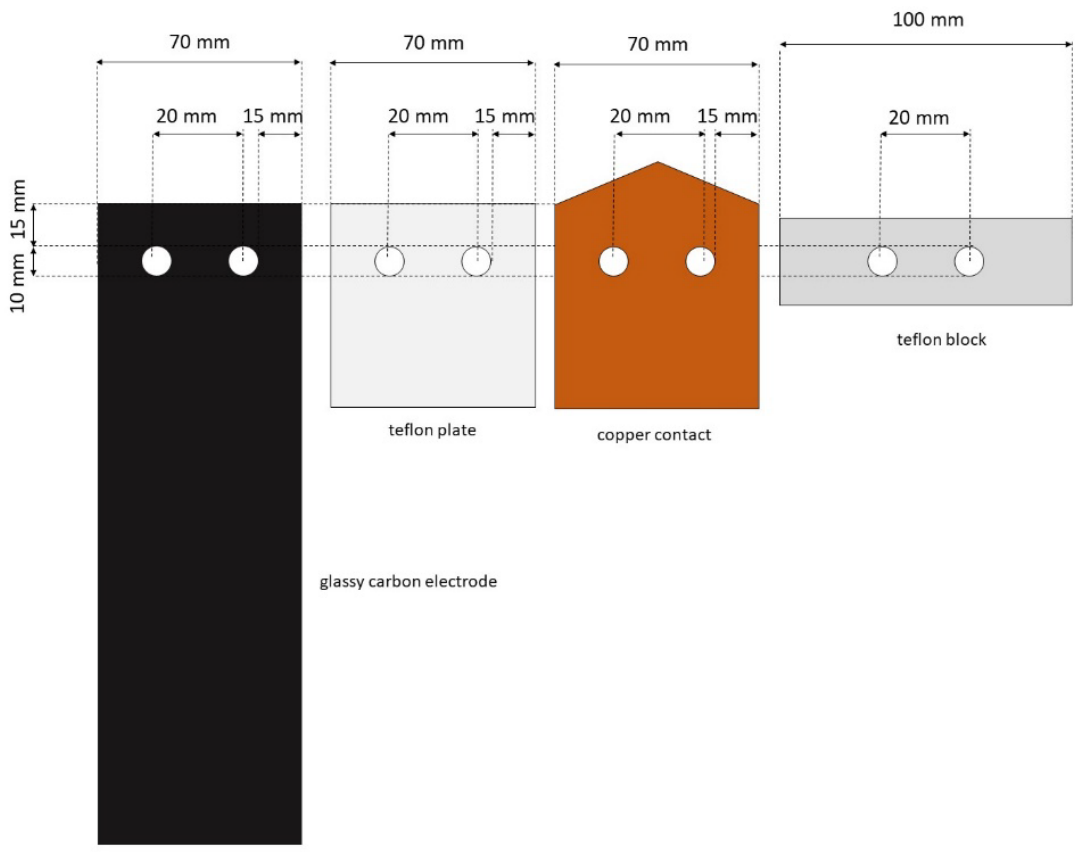

Figure S 4. Technical drawing of the electrode stack. A) Front view. B) Side view. C) Single components.

\section{$2.32 \mathrm{~cm} \times 6 \mathrm{~cm}$ Flow Cell}

2,4-Dimethylphenol was dissolved in a solution of HFIP with pyridine. For a single pass through the flow cell, the solution was pumped once through the electrochemical flow cell at the required flow rate. For a cascade electrolysis, the solution was pumped multiple times with respective several times higher 
flow rates through the cell. In each case, the corresponding electrochemical parameters were applied during electrolysis (for more details see Table S 2). Before the electrolyte was collected, a volume of $2 \mathrm{~mL}$ was discarded to ensure that the whole collected electrolyte was electrolyzed under the given conditions. A $5 \mathrm{~mL}$ aliquot of the electrolyzed mixture was taken and the solvent was recovered in vacuo $\left(50^{\circ} \mathrm{C}, 200-70\right.$ mbar). The crude coupling product was purified by column chromatography $\left(\mathrm{SiO}_{2}\right.$, cyclohexane/ethyl acetate) and dried under reduced pressure to obtain the pure product.

A detailed description of this set up was published recently (Figure S 5). ${ }^{3}$ This setup is commercially available as ElectraSyn flow (IKA Werke GmbH \& Co. KG, Staufen, Germany). Dimensions of BDD electrode $\left(15 \mu \mathrm{m}\right.$ diamond layer on silicon, DIACHEM ${ }^{\mathrm{TM}}$ obtained from CONDIAS, Itzehoe, Germany), glassy carbon electrode (SIGRADUR ${ }^{\circledR}$ G, obtained from HTW Hochtemperatur Werkstoffe $\mathrm{GmbH}$, Thierhaupten, Germany) and, graphite electrode (isostatic graphite, obtained from SGL carbon, Bonn, Germany.) is $6.0 \times 2.0 \times 0.3 \mathrm{~cm}$ leading to an anode surface of $12 \mathrm{~cm}^{2}$.

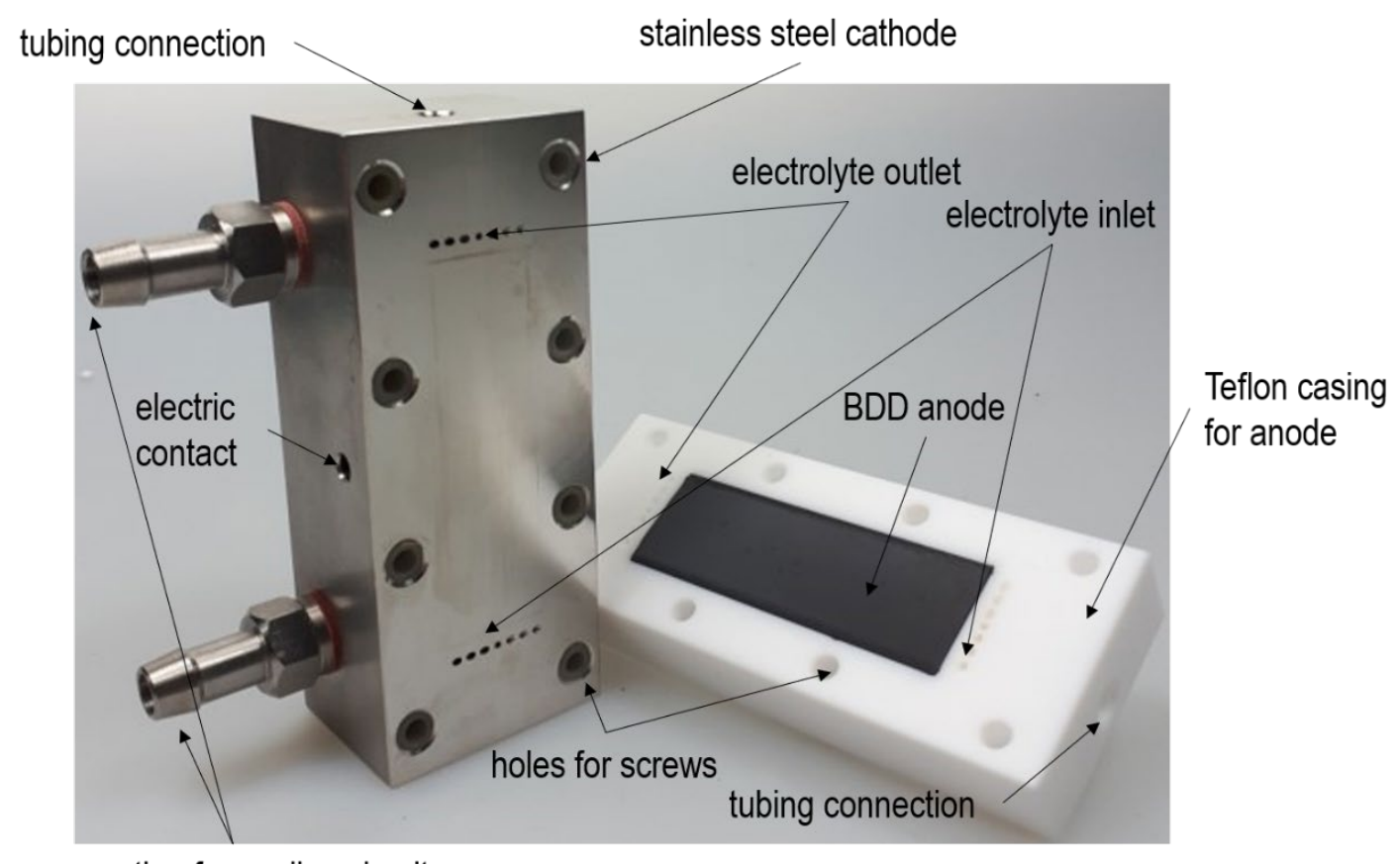

connection for cooling circuit

Figure S 5. $2 \mathrm{~cm} \times 6 \mathrm{~cm}$ flow cell with a temperature-controlled stainless steel block as cathode and a Teflon-cased BDD anode. 
Table S 2. Conditions for the optimization of the electrochemical synthesis of 3,3',5,5'-tetramethyl-2,2'-biphenol (2) in the $2 \mathrm{~cm} \times 6 \mathrm{~cm}$ flow cell.

\begin{tabular}{|c|c|c|c|c|c|c|c|c|c|}
\hline Entry & $\begin{array}{c}\text { Volume fraction } \\
\text { of pyridine } \\
(\text { vol } \%)\end{array}$ & $\begin{array}{c}\text { Concentration } \\
\text { of } \mathbf{1} \\
(\mathrm{mol} / \mathrm{L})\end{array}$ & $\begin{array}{l}\text { Flow rate } \\
(\mathrm{mL} / \mathrm{min})\end{array}$ & $\begin{array}{l}\text { Anode } \\
\text { material }\end{array}$ & $\begin{array}{l}\text { Cascade } \\
\text { steps }\end{array}$ & $\begin{array}{l}\text { Applied } \\
\text { charge } \\
(F)\end{array}$ & $\begin{array}{c}\text { Current } \\
\text { density } \\
\left(\mathrm{mA} / \mathrm{cm}^{2}\right)\end{array}$ & $\begin{array}{c}\text { Temperature } \\
\left({ }^{\circ} \mathrm{C}\right)\end{array}$ & $\begin{array}{c}\text { Yield of } 2 \\
(\%)\end{array}$ \\
\hline 1 & 1.0 & 0.5 & 0.45 & BDD & 1 & 1.0 & 30 & 20 & 25 \\
\hline 2 & 2.5 & 0.5 & 0.45 & BDD & 1 & 1.0 & 30 & 20 & 24 \\
\hline 3 & 5.0 & 0.5 & 0.45 & BDD & 1 & 1.0 & 30 & 20 & 26 \\
\hline 4 & 7.5 & 0.5 & 0.45 & BDD & 1 & 1.0 & 30 & 20 & 26 \\
\hline 5 & 10.0 & 0.5 & 0.45 & BDD & 1 & 1.0 & 30 & 20 & 25 \\
\hline 6 & 12.5 & 0.5 & 0.45 & BDD & 1 & 1.0 & 30 & 20 & 24 \\
\hline 7 & 15.0 & 0.5 & 0.45 & BDD & 1 & 1.0 & 30 & 20 & 20 \\
\hline 9 & 5 & 0.5 & 0.45 & BDD & 1 & 1.0 & 30 & 20 & 26 \\
\hline 10 & 5 & 0.75 & 0.30 & BDD & 1 & 1.0 & 30 & 20 & 37 \\
\hline 11 & 5 & 1.0 & 0.22 & BDD & 1 & 1.0 & 30 & 20 & 37 \\
\hline 12 & 5 & 1.25 & 0.18 & BDD & 1 & 1.0 & 30 & 20 & 39 \\
\hline 13 & 5 & 1.5 & 0.15 & BDD & 1 & 1.0 & 30 & 20 & 37 \\
\hline 14 & 5 & 1.75 & 0.13 & BDD & 1 & 1.0 & 30 & 20 & 39 \\
\hline 15 & 5 & 2.0 & 0.11 & BDD & 1 & 1.0 & 30 & 20 & 30 \\
\hline
\end{tabular}




\begin{tabular}{|c|c|c|c|c|c|c|c|c|c|}
\hline Entry & $\begin{array}{l}\text { Volume fraction } \\
\text { of pyridine } \\
\text { (vol \%) }\end{array}$ & $\begin{array}{c}\text { Concentration } \\
\text { of } \mathbf{1} \\
(\mathrm{mol} / \mathrm{L})\end{array}$ & $\begin{array}{l}\text { Flow rate } \\
(\mathrm{mL} / \mathrm{min})\end{array}$ & $\begin{array}{l}\text { Anode } \\
\text { material }\end{array}$ & $\begin{array}{c}\text { Cascade } \\
\text { steps }\end{array}$ & $\begin{array}{l}\text { Applied } \\
\text { charge } \\
(F) \\
\end{array}$ & $\begin{array}{c}\text { Current } \\
\text { density } \\
\left(\mathrm{mA} / \mathrm{cm}^{2}\right) \\
\end{array}$ & $\begin{array}{c}\text { Temperature } \\
\left({ }^{\circ} \mathrm{C}\right)\end{array}$ & $\begin{array}{c}\text { Yield of } 2 \\
(\%)\end{array}$ \\
\hline 16 & 5 & 1.25 & 0.18 & BDD & 1 & 1.0 & 30 & 20 & 40 \\
\hline 17 & 5 & 1.25 & 0.18 & Glassy carbon & 1 & 1.0 & 30 & 20 & 43 \\
\hline 18 & 5 & 1.25 & 0.18 & Graphite & 1 & 1.0 & 30 & 20 & 35 \\
\hline 19 & 5 & 1.25 & 0.90 & Glassy carbon & 5 & 1.0 & 30 & 20 & 57 \\
\hline 20 & 5 & 1.25 & 1.79 & Glassy carbon & 10 & 1.0 & 30 & 20 & 58 \\
\hline 21 & 5 & 1.25 & 1.79 & Glassy carbon & 8 & 0.8 & 30 & 20 & 57 \\
\hline 22 & 5 & 1.25 & 2.67 & Glassy carbon & 15 & 1.0 & 30 & 20 & 52 \\
\hline 23 & 5 & 1.25 & 2.67 & Glassy carbon & 12 & 0.8 & 30 & 20 & 58 \\
\hline 24 & 5 & 1.25 & 3.58 & Glassy carbon & 20 & 1.0 & 30 & 20 & 56 \\
\hline 25 & 5 & 1.25 & 3.58 & Glassy carbon & 16 & 0.8 & 30 & 20 & 58 \\
\hline 26 & 5 & 1.25 & 0.60 & Glassy carbon & 8 & 0.8 & 10 & 20 & 53 \\
\hline 27 & 5 & 1.25 & 1.19 & Glassy carbon & 8 & 0.8 & 20 & 20 & 53 \\
\hline 28 & 5 & 1.25 & 1.79 & Glassy carbon & 8 & 0.8 & 30 & 20 & 57 \\
\hline 29 & 5 & 1.25 & 2.39 & Glassy carbon & 8 & 0.8 & 40 & 20 & 61 \\
\hline 30 & 5 & 1.25 & 2.98 & Glassy carbon & 8 & 0.8 & 50 & 20 & 59 \\
\hline 31 & 5 & 1.25 & 3.58 & Glassy carbon & 8 & 0.8 & 60 & 20 & 61 \\
\hline
\end{tabular}




\begin{tabular}{|c|c|c|c|c|c|c|c|c|c|}
\hline Entry & $\begin{array}{c}\text { Volume fraction } \\
\text { of pyridine } \\
(\text { vol \%) }\end{array}$ & $\begin{array}{c}\text { Concentration } \\
\text { of } \mathbf{1} \\
(\mathrm{mol} / \mathrm{L})\end{array}$ & $\begin{array}{l}\text { Flow rate } \\
(\mathrm{mL} / \mathrm{min})\end{array}$ & $\begin{array}{c}\text { Anode } \\
\text { material }\end{array}$ & $\begin{array}{c}\text { Cascade } \\
\text { steps }\end{array}$ & $\begin{array}{l}\text { Applied } \\
\text { charge } \\
(F)\end{array}$ & $\begin{array}{c}\text { Current } \\
\text { density } \\
\left(\mathrm{mA} / \mathrm{cm}^{2}\right) \\
\end{array}$ & $\begin{array}{c}\text { Temperature } \\
\left({ }^{\circ} \mathrm{C}\right)\end{array}$ & $\begin{array}{c}\text { Yield of } 2 \\
(\%)\end{array}$ \\
\hline 32 & 5 & 1.25 & 4.18 & Glassy carbon & 8 & 0.8 & 70 & 20 & 57 \\
\hline 33 & 5 & 1.25 & 4.78 & Glassy carbon & 8 & 0.8 & 80 & 20 & 57 \\
\hline 34 & 5 & 1.25 & 3.58 & Glassy carbon & 8 & 0.8 & 60 & 0 & 59 \\
\hline 35 & 5 & 1.25 & 3.58 & Glassy carbon & 8 & 0.8 & 60 & 10 & 59 \\
\hline 36 & 5 & 1.25 & 3.58 & Glassy carbon & 8 & 0.8 & 60 & 20 & 58 \\
\hline 37 & 5 & 1.25 & 3.58 & Glassy carbon & 8 & 0.8 & 60 & 30 & 58 \\
\hline 38 & 5 & 1.25 & 3.58 & Glassy carbon & 8 & 0.8 & 60 & 40 & 56 \\
\hline 39 & 5 & 1.25 & 3.58 & Glassy carbon & 8 & 0.8 & 60 & 50 & 57 \\
\hline
\end{tabular}




\section{$2.4 \quad 4 \mathrm{~cm} \times 12 \mathrm{~cm}$ Flow Cell}

2,4-Dimethylphenol $(\mathrm{c}=1.25 \mathrm{~mol} / \mathrm{L})$ was dissolved in a solution of HFIP with 5 vol $\%$ pyridine. The solution was pumped eight times through the electrochemical flow cell at a flow rate of $14.3 \mathrm{~mL} / \mathrm{min}$ (in total $0.8 F$ ). The cell was equipped with a glassy carbon anode and stainless steel cathode. A current density of $60 \mathrm{~mA} / \mathrm{cm}^{2}$ was applied (for more details see Table S 3). Before the electrolyte was collected, a volume of $5 \mathrm{~mL}$ was discarded to ensure that the whole collected electrolyte was electrolyzed under the same conditions. A $5 \mathrm{~mL}$ aliquot of the electrolyzed mixture was taken and the solvent was recovered in vacuo $\left(50^{\circ} \mathrm{C}, 200-70 \mathrm{mbar}\right)$. The crude coupling product was purified by column chromatography $\left(\mathrm{SiO}_{2}\right.$, cyclohexane/ethyl acetate) and dried under reduced pressure to obtain the pure product.

Table S 3. Screening of the temperature for the electrochemical synthesis of 3,3',5,5'-tetramethyl-2,2'-biphenol (2) in the $4 \mathrm{~cm} \times 12 \mathrm{~cm}$ flow cell via a cascade electrolysis.

\begin{tabular}{|c|c|c|}
\hline Entry & $\begin{array}{c}\text { Temperature } \\
\left({ }^{\circ} \mathrm{C}\right)\end{array}$ & $\begin{array}{c}\text { Yield of } 2 \\
(\%)^{\mathrm{b}}\end{array}$ \\
\hline 1 & 20 & 57 \\
\hline 2 & 10 & 57 \\
\hline 3 & 0 & 59 \\
\hline
\end{tabular}

A detailed description of this set up was published recently (Figure S 6). ${ }^{4}$ Dimensions of the glassy carbon electrode (SIGRADUR ${ }^{\circledR}$ G, obtained from HTW Hochtemperatur Werkstoffe GmbH, Thierhaupten, Germany) is $12.0 \times 4.0 \times 0.3 \mathrm{~cm}$ providing an anode surface of $48 \mathrm{~cm}^{2}$. 

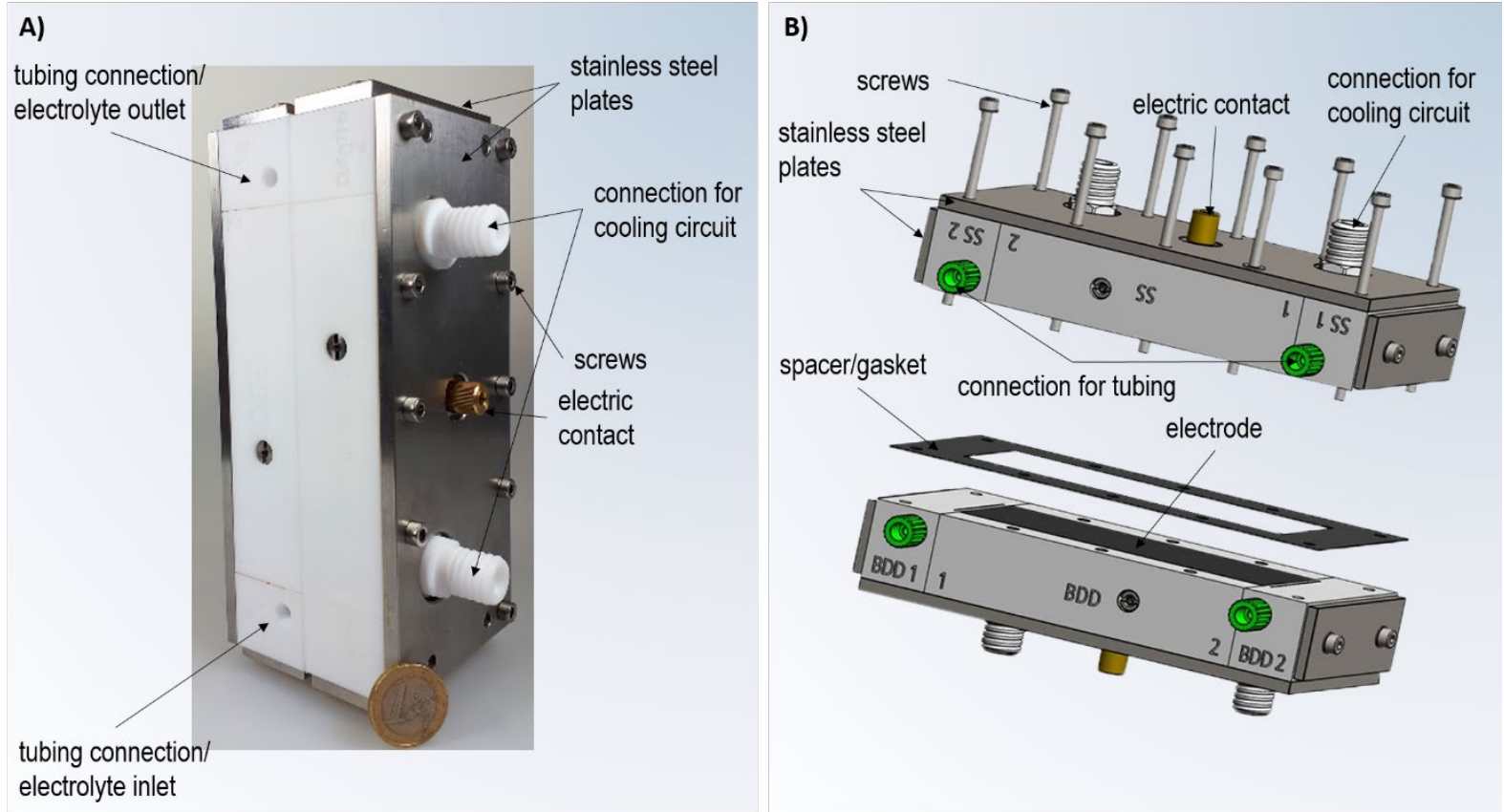

Figure S 6. A) Completely mounted $4 \mathrm{~cm} \times 12 \mathrm{~cm}$ flow cell and a one Euro coin (diameter: $23.25 \mathrm{~mm}$ ) for comparison. B) Explosion drawing of the $4 \mathrm{~cm} \times 12 \mathrm{~cm}$ flow cell. 


\section{GC Calibration via an Internal Standard Method}

\subsection{Protocol for the Generation of the Calibration Curve}

A defined amount of 3,3',5,5'-tetramethyl-2,2'-biphenol (2) (Table S 4) and $50 \mu \mathrm{L} n$-octylbenzene $(42.9 \mathrm{mg}$ ) as internal standard were dissolved in $5 \mathrm{~mL}$ ethyl acetate. Subsequently, a GC-vial was filled with $50 \mu \mathrm{L}$ of this this solution and replenished with ethyl acetate. After homogenization of this solution a gas chromatogram was determined. The quotients were formed from the mass of $\mathbf{2}\left(\mathrm{m}_{\mathrm{P}}\right)$ and the mass of $n$-octylbenzene $\left(\mathrm{m}_{\mathrm{S}}\right)$ as well as from the area of the GC peak of $2\left(\mathrm{~A}_{\mathrm{P}}\right)$ and the area of the GC peak of $n$-octylbenzene $\left(\mathrm{A}_{\mathrm{S}}\right)$. Based on this quotients a calibration curve was plotted (Figure $\mathrm{S} 7$ ).

Table S 4. Data of the internal calibration.

\begin{tabular}{|c|c|c|c|c|c|}
\hline Entry & $\begin{array}{c}\mathrm{m}_{\mathrm{P}} \\
(\mathrm{mg})\end{array}$ & $\mathrm{m}_{\mathrm{P}} / \mathrm{m}_{\mathrm{S}}$ & $\mathrm{A}_{\mathrm{P}}$ & $\mathrm{A}_{\mathrm{S}}$ & $\mathrm{A}_{\mathrm{p}} / \mathrm{A}_{\mathrm{S}}$ \\
\hline 1 & 40.7 & 0.9 & 57055 & 96650 & 0.6 \\
\hline 2 & 83.3 & 1.9 & 240428 & 162596 & 1.5 \\
\hline 3 & 119.6 & 2.8 & 334808 & 149189 & 2.2 \\
\hline 4 & 158.0 & 3.7 & 406765 & 139355 & 2.9 \\
\hline 5 & 201.4 & 4.7 & 408698 & 113105 & 3.6 \\
\hline 6 & 238.6 & 5.6 & 440373 & 98917 & 4.5 \\
\hline 7 & 281.5 & 6.6 & 450561 & 93349 & 4.8 \\
\hline 8 & 316.6 & 7.4 & 456169 & 81530 & 5.6 \\
\hline 9 & 359.8 & 8.4 & 418939 & 66784 & 6.3 \\
\hline 10 & 401.6 & 9.4 & 447892 & 64581 & 6.9 \\
\hline
\end{tabular}




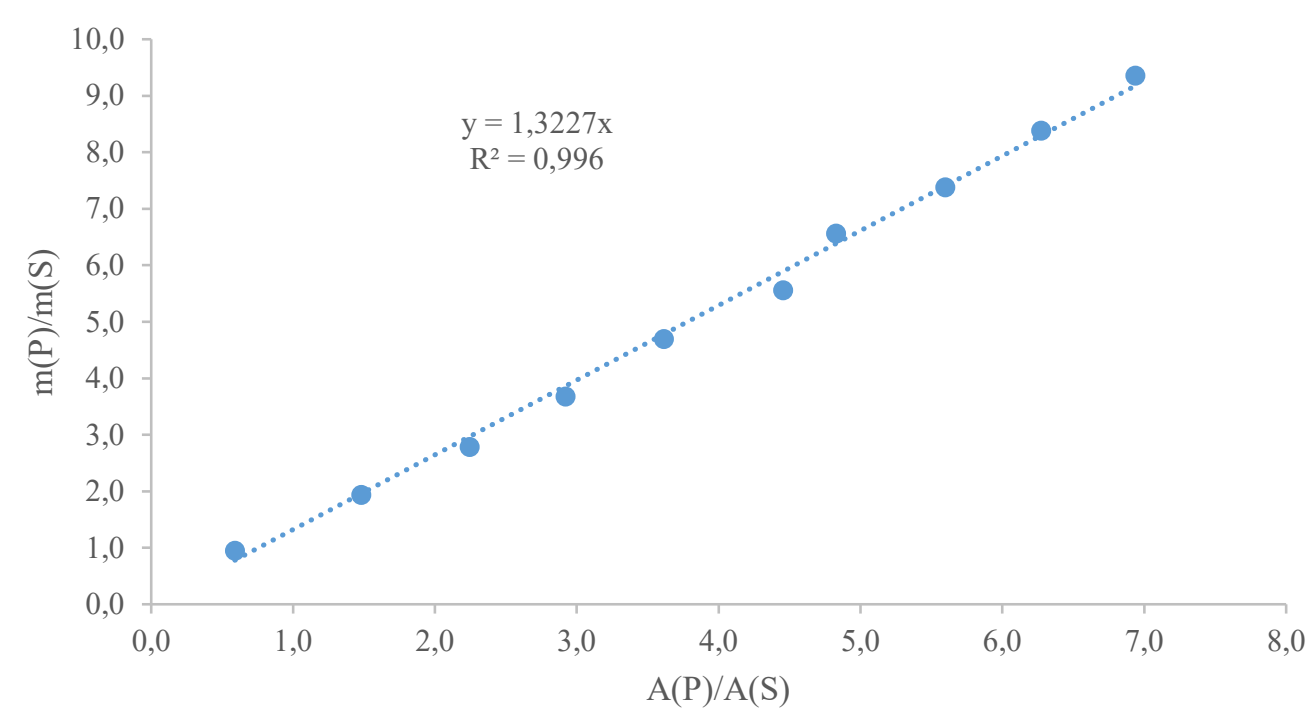

Figure S 7. Calibration curve.

\subsection{Protocol for the Analysis of an Electrolyte Sample}

After the electrolysis the solvent of a $2 \mathrm{~mL}$ (in case of the 5 step cascade $3 \mathrm{~mL}$ ) sample was recovered in vacuo $\left(50^{\circ} \mathrm{C} .200-70 \mathrm{mbar}\right)$. To the residue $50 \mu \mathrm{L} n$-octylbenzene was added and the mixture was dissolved in $5 \mathrm{~mL}$ ethyl acetate. $50 \mu \mathrm{L}$ of this solution was filtrated over $1.5 \mathrm{~g}$ silica gel Geduran ${ }^{\circledR} \mathrm{Si} 60$ into a GC-vial (eluent: ethyl acetate) and analysed via gas chromatography. Based on the calibration curve (Figure S 7) the amount of 3,3',5,5'-tetramethyl-2,2'-biphenol $\left(\mathrm{m}_{\mathrm{P}}^{\mathrm{GC}}\right)$ can be calculated via equation (S1).

$$
\mathrm{m}_{\mathrm{P}}^{\mathrm{GC}}=42.9 \mathrm{mg} \cdot\left(13227 \cdot \mathrm{A}_{\mathrm{P}} / \mathrm{AS}_{\mathrm{S}}\right)
$$

\subsection{Data for the Cascade Reactions}

The via equation ( $\mathrm{S} 1$ ) calculated amounts of 3,3',5,5'-tetramethyl-2,2'-biphenol $\left(\mathrm{m}_{\mathrm{P}}^{\mathrm{GC}}\right)$ for the 5 step to 20 step cascade are shown in Table $\mathrm{S} 5$. 
Table S 5. $\mathrm{mP}^{\mathrm{GC}}$ of the individual cascade steps.

\begin{tabular}{|c|c|c|c|c|}
\hline \multirow[b]{2}{*}{$\begin{array}{l}\text { Amount of Charge } \\
\qquad(F)\end{array}$} & \multicolumn{4}{|c|}{$\begin{array}{l}\mathrm{m}_{\mathrm{P}}^{\mathrm{GC}} \text { of the individual cascade steps } \\
(\mathrm{mg})\end{array}$} \\
\hline & $5 x$ & $10 x$ & $15 x$ & $20 \times$ \\
\hline 0.050 & & & & 17 \\
\hline 0.067 & & & 22 & \\
\hline 0.100 & & 33 & & 33 \\
\hline 0.133 & & & 43 & \\
\hline 0.150 & & & & 53 \\
\hline 0.200 & 45 & 67 & 63 & 67 \\
\hline 0.250 & & & & 89 \\
\hline 0.267 & & & 89 & \\
\hline 0.300 & & 96 & & 102 \\
\hline 0.333 & & & 110 & \\
\hline 0.350 & & & & 114 \\
\hline 0.400 & 96 & 129 & 133 & 133 \\
\hline 0.450 & & & & 148 \\
\hline 0.467 & & & 153 & \\
\hline 0.500 & & 161 & & 162 \\
\hline 0.533 & & & 169 & \\
\hline 0.550 & & & & 184 \\
\hline 0.600 & 140 & 178 & 187 & 188 \\
\hline 0.650 & & & & 206 \\
\hline 0.667 & & & 200 & \\
\hline 0.700 & & 196 & & 209 \\
\hline 0.733 & & & 213 & \\
\hline 0.750 & & & & 219 \\
\hline 0.800 & 210 & 207 & 213 & 207 \\
\hline 0.850 & & & & 220 \\
\hline
\end{tabular}




\begin{tabular}{|l|l|l|l|l|}
\hline 0.867 & & & 216 & \\
\hline 0.900 & & 208 & & 226 \\
\hline 0.933 & & & 220 & \\
\hline 0.950 & & & & 222 \\
\hline 1.000 & 227 & 197 & 209 & 232 \\
\hline
\end{tabular}

The GC yield of 3,3',5,5'-tetramethyl-2,2'-biphenol can be calculated via equation (S2) for the 5 step cascade and equation (S3) for the 10 to 20 step cascades (Table S 6).

$$
\begin{aligned}
& \text { GC yield }=\frac{2 \cdot \mathrm{m}_{\mathrm{P}}^{\mathrm{GC}}}{3.0 \mathrm{mmol} \cdot 242,31 \mathrm{~g} / \mathrm{mol}} \cdot 100 \% \\
& \text { GC yield }=\frac{2 \cdot \mathrm{m}_{\mathrm{P}}^{\mathrm{GC}}}{2.5 \mathrm{mmol} \cdot 242,31^{\mathrm{g}} / \mathrm{mol}} \cdot 100 \%
\end{aligned}
$$

Table S 6. GC yield of the individual cascade steps.

\begin{tabular}{|c|c|c|c|c|}
\hline & \multicolumn{4}{|c|}{ GC yield of the individual cascade steps } \\
\hline $\begin{array}{c}\text { Amount of Charge } \\
(F)\end{array}$ & $5 \times$ & $10 \times$ & $15 \times$ & $20 \times$ \\
\hline 0.050 & & & & 6 \\
\hline 0.067 & & & 7 & \\
\hline 0.100 & & 11 & & 11 \\
\hline 0.133 & & & 14 & \\
\hline 0.150 & 12 & 22 & 21 & 22 \\
\hline 0.200 & & & & 30 \\
\hline 0.250 & & & 29 & \\
\hline 0.267 & & 32 & & 34 \\
\hline 0.300 & & & 36 & \\
\hline 0.333 & & & & \\
\hline
\end{tabular}




\begin{tabular}{|c|c|c|c|c|}
\hline 0.350 & & & & 38 \\
\hline 0.400 & 26 & 42 & 44 & 44 \\
\hline 0.450 & & & & 49 \\
\hline 0.467 & & & 51 & \\
\hline 0.500 & & 53 & & 54 \\
\hline 0.533 & & & 56 & \\
\hline 0.550 & & & & 61 \\
\hline 0.600 & 39 & 59 & 62 & 62 \\
\hline 0.650 & & & & 68 \\
\hline 0.667 & & & 66 & \\
\hline 0.700 & & 65 & & 69 \\
\hline 0.733 & & & 70 & \\
\hline 0.750 & & & & 72 \\
\hline 0.800 & 58 & 68 & 70 & 69 \\
\hline 0.850 & & & & 73 \\
\hline 0.867 & & & 71 & \\
\hline 0.900 & & 68 & & 75 \\
\hline 0.933 & & & 73 & \\
\hline 0.950 & & & & 73 \\
\hline 1.000 & 63 & 65 & 69 & 71 \\
\hline
\end{tabular}




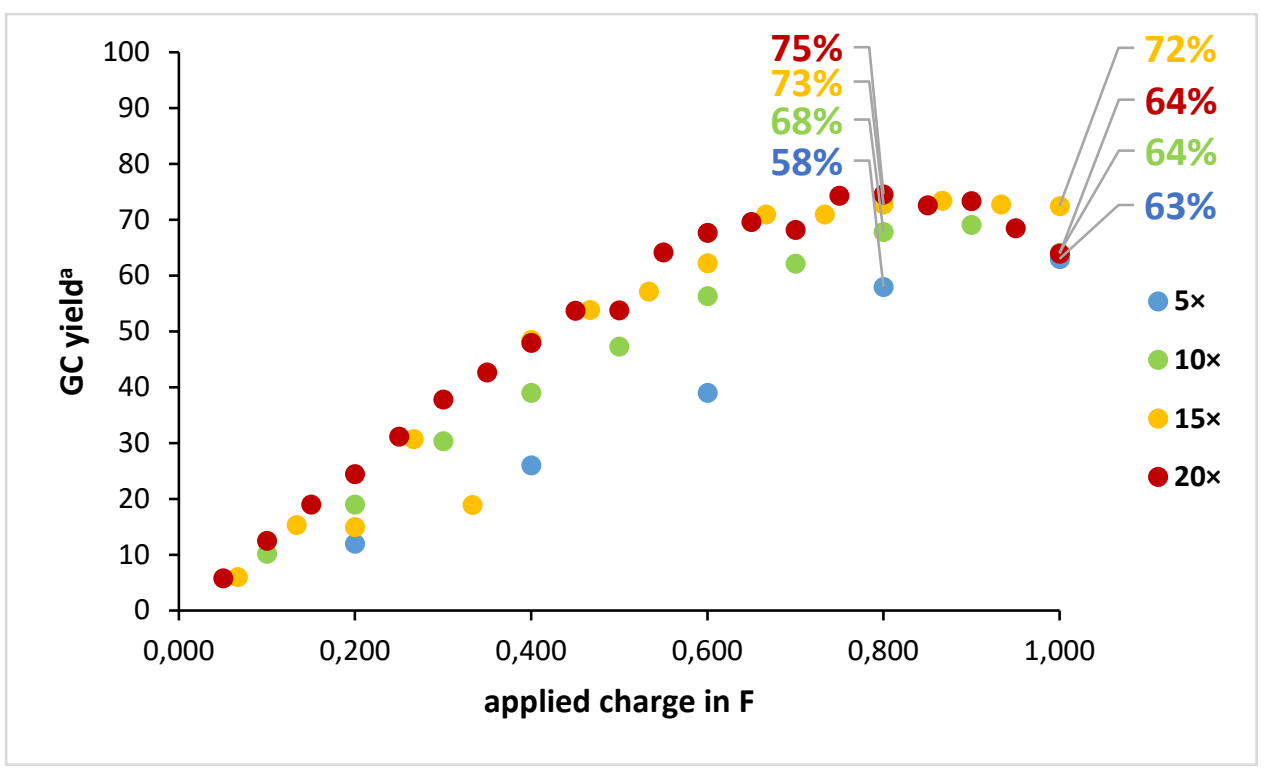

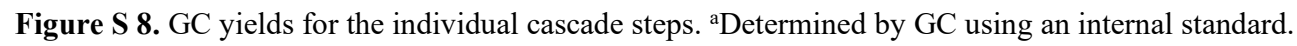

\section{Analytical Data of 3,3',5,5'-Tetramethyl-2,2'-biphenol (2)}

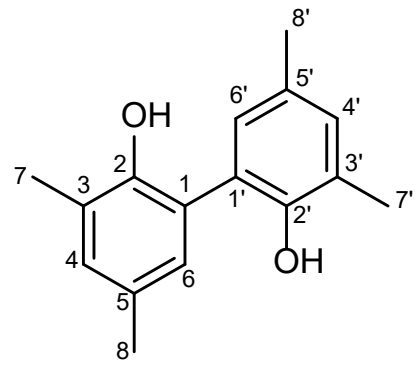

2

${ }^{1}$ H NMR (400 MHz, CDCl3): $\delta[\mathrm{ppm}]=7.01-7.00(\mathrm{~m}, 2 \mathrm{H}, H-6, H-6$ ') $6.87-6.86(\mathrm{~m}, 2 \mathrm{H}, H-4, H-$ 4'), 5.07 (s, 2H, $O H$ ), 2.28 (s, 12H, H-7, H-7', H-8, H-8').

${ }^{13}$ C NMR (101 MHz, CDCl3): $\delta[\mathrm{ppm}]=149.2,132.0,130.0,128.5,125.2,122.2,20.5,16.2$.

MS (FD): $m / z=242.3$.

$\mathbf{R}_{\mathbf{f}}: 0.35$ (cyclohexane/ethyl acetate $\left.=9: 1\right)$

mp: $137^{\circ} \mathrm{C}$

Analytical data in agreement with those previously reported. ${ }^{5}$ 


\section{${ }^{1} \underline{H}$ NMR of 3,3',5,5'-Tetramethyl-2,2'-biphenol (2)}

528.1.fid

AT Walduogel / Name Selt / Code MSE102

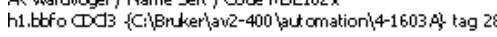

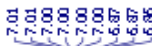

查
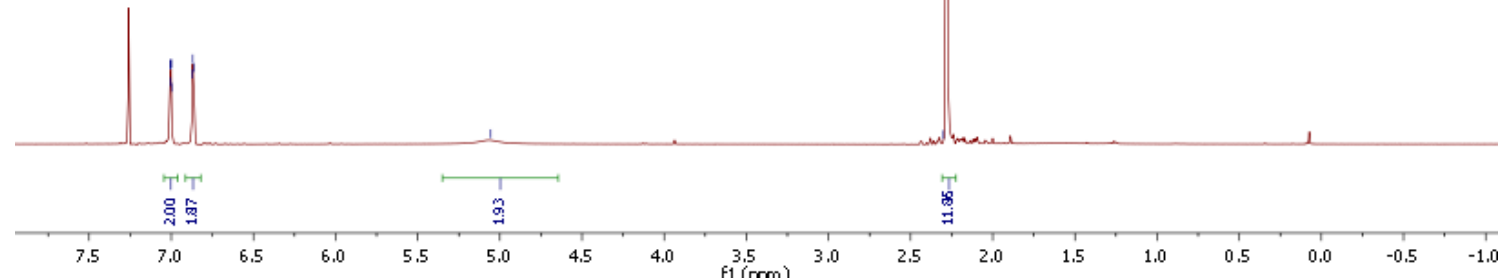

\section{${ }^{13}$ C NMR of 3,3',5,5'-Tetramethyl-2,2'-biphenol (2)}

351.2.fid

/ Name Selt / Code MEE102

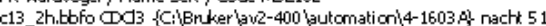

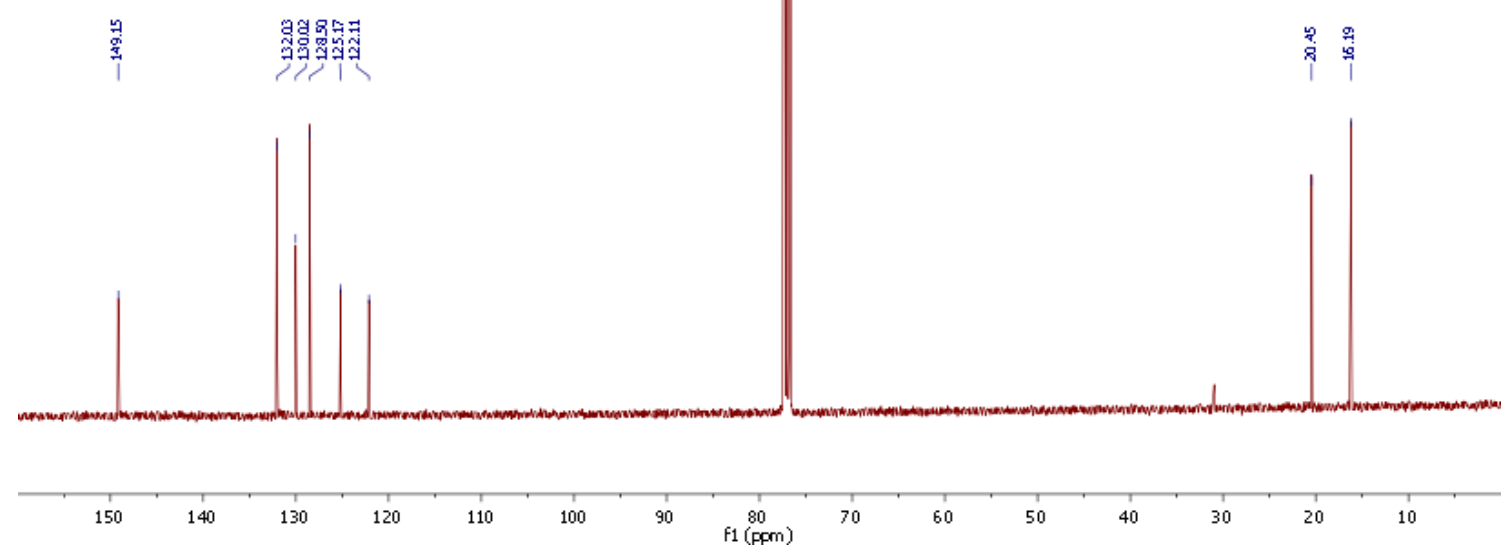


FD MS of 3,3',5,5'-Tetramethyl-2,2'-biphenol (2)

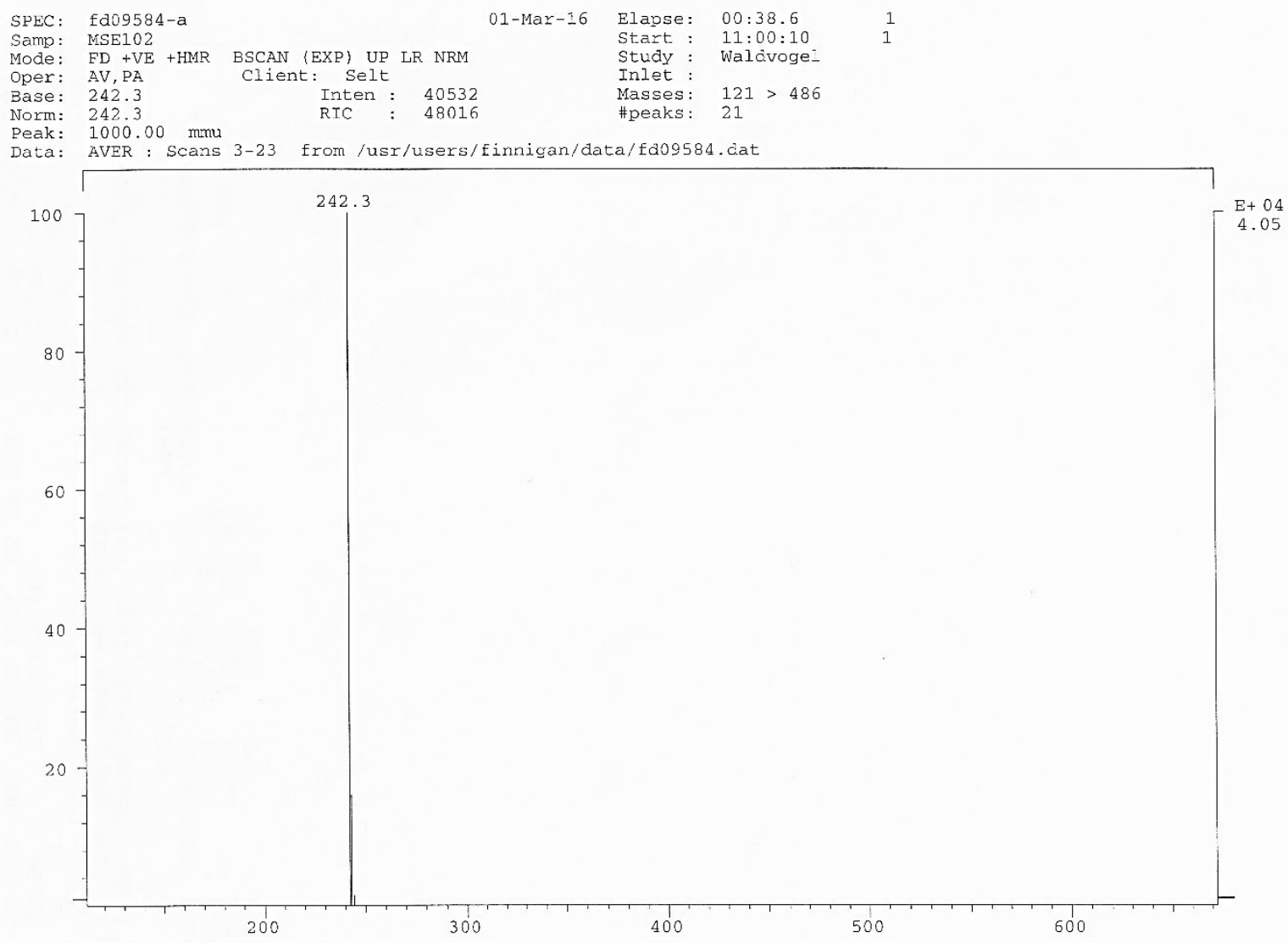




\section{References}

(1) Armarego, W. L. F.; Chai, C. L. L. Purification of Laboratory Chemicals, 7. ed.; Elsevier: Amsterdam, 2013.

(2) Gütz, C.; Klöckner, B.; Waldvogel, S. R. Electrochemical Screening for Electroorganic Synthesis. Org. Process Res. Dev. 2016, 20, 26-32.

(3) Gütz, C.; Stenglein, A.; Waldvogel, S. R. Highly Modular Flow Cell for Electroorganic Synthesis. Org. Process Res. Dev. 2017, 21, 771-778.

(4) Gleede, B.; Selt, M.; Gütz, C.; Stenglein, A.; Waldvogel, S. R. Large, Highly Modular Narrow-Gap Electrolytic Flow Cell and Application in Dehydrogenative Cross-Coupling of Phenols. Org. Process Res. Dev. 2019, DOI:10.1021/acs.oprd.9b00451.

(5) Kirste, A.; Hayashi, S.; Schnakenburg, G.; Malkowsky, I. M.; Stecker, F.; Fischer, A.; Fuchigami, T.; Waldvogel, S. R. Highly Selective Electrosynthesis of Biphenols on Graphite Electrodes in Fluorinated Media. Chem. - Eur. J 2011, 17, 14164-14169. 